\title{
CERTIFICATION OF AGRARIAN ENTERPRISES-PRODUCERS OF ORGANIC PRODUCTS IN ORDER TO ENTER EUROPEAN MARKETS
}

\author{
Larisa Marmul', Elena Krukovskaya²
}

\begin{abstract}
The objective of the article is to consider the actual issues of institutional support for the development of agrarian enterprises producing organic products in Ukraine, as well as the definition of formal and informal institutions for the regulation of organic products market. Methodology. While the study, the following methods were used:analytical method-toidentify the basicrulesand proceduresfor the developmentoforganicproduction and the structuring of its institutional environment; synthesis method - to assess the state of development of institutes and infrastructure of the industry; abstracting and logical modelling of the system of interconnections and regulating and stimulating influences of environmental elements on the development of organic production. Results. The article deals with topical issues of institutional support for the development of agrarian enterprises producing organic products in Ukraine. There were established formal and informal institutions for regulating the organic products market. The features of placement and specialization of agrarian enterprises for the production of organic products are revealed. Certain institutions of certification of production and products are described as separate institutions. The further prospects of development of agrarian enterprises producing organic products on the basis of improvement of institutional regulation and certification are substantiated. Practical importance. The results of the study can be taken into account and used for the development of state and industry programs for the development of organic production. Scientific novelty. The systematic vision of the development environment of organic production in Ukraine is substantiated, which, in contrast to the existing views, is interpreted as an interconnected and interdependent set of elements regulated by managerial influences of the state and industry levels.
\end{abstract}

Key words: organic production, agrarian enterprises, institutional regulation, certification, market, development, improvement.

JEL Classification: P42, D02, Q13, F63

\section{Introduction}

Objectively, the formation of the system of institutional provision for the sustainable development of organic production in Ukraine cannot take place apart from a solution of ecological problems caused by the whole agricultural sector. The necessity of solution motivates state authorities to participate in and sign the numerous nature-protecting conventions since any subject of economic management performs in a certain institutional environment directly interacting with and effecting upon it.

This is why the institutional environment formed in agrarian sector of the country in the process of transformational changes in economics and other spheres of human life activity is characterized by the influence of formal and informal institutions on the efficiency of performance of the subjects of economic management inclusive of those active in the production of organic agrarian commodities. Such an influence provides for the balance of agro-landscapes and warrants for sustainable development of ecological, social, and production-economic spheres of rural territories.

In our opinion, the preservation of natural resources in the process of economic management should be considered in conjunction with the necessity of promotion of resource-preserving ecologically safe technologies. The task is expected to be favoured by way of introduction of the institutions of the owners and users' social and economic-legal responsibility for the provision of reproduction of agricultural lands fertility. As well, it is referred to the organizationaleconomic mechanism of organic agricultural

\footnotetext{
Corresponding author:

${ }^{1}$ Kherson State Agrarian University, Ukraine.

E-mail: marmul61@ukr.net

${ }^{2}$ Kherson State Agrarian University, Ukraine.

E-mail: marina0108@meta.ua
} 
production, optimization of the lands' phytosanitary state and improvement of agro-technologies. It is due to these reasons that further economic activity in organic management is possible only within respective institutional limits.

\section{Current issues of institutional support for the development of agrarian enterprises with organic production in Ukraine}

Development of agrarian enterprises with organic economic management would solve problems related to the saving of natural resources, the establishment of harmlessandnon-wastetechnologies, andenvironmental ecological "turnover". It must be emphasized that once there appeared an increasing demand for it, Ukraine possesses great potential for the production of organic commodities, their export and domestic consumption (Marmul, Novak, 2016). Since capable of helping to improve the financial-economic, social, and ecological state of commodity producers, organic production would add to the complex development of the agrarian sector and improvement of public health. However, the concept of "organic production" is not yet clearly defined and it is still difficult to give a clear definition of it, for, at all stages of its production, the end product does not have to change its properties and should maximally present its natural qualities to the consumer.

Institutional provision for the development of production of organic agricultural commodities represents a fundamental basis of agrarian nature use. It effects on interrelations between subjects of economic management and the environment and determines the nature of institutional changes in the sphere of natural resource use. Institutional changes are the driving transformational-modifying processes that provide for qualitative changes within the system of agrarian resource use, as well as for the modelling of vectors of organic production development.

Formation and further improvement of the institutional environment for the development of organic agricultural production should rest on the social-economic and ecological interests of economic entities. It is necessary to take into account the market position in the sector and the degree of infrastructure development; legal support and protection of subjects of the organic economy; their (subjects') provision with financial-investment and other resources; population's demand for organic food commodities and industrial demand for organic agricultural raw materials; ways of use of and capacity to reproduce nature-resource potential; and environmental monitoring efficiency. It seems reasonable that economic entities were stimulated to implement in organic agricultural production the resource-saving and eco-safe technologies.

Thus, the formation of the system of institutional provision for the development of organic agriculture presupposes availability of harmonized formal and informal institutions that would determine and regulate its territorial, social, production-economic, ecological, legal, and organizational-managerial parameters. Realization of organic production in Ukraine shall become a success only with visible shifts in the system of fundamental moral-ethic principles, restrictions and rules, values and interests that predefine economic interaction and social responsibility of the subjects of economic management, consumers, state institutions, big agro-holdings, etc. (Ihnatenko, 2015). The components of the institutional environment for organic production establish the "rules of the game" within a threefold system of social-economic, legal or political institutions of formal content and informal ideological institutions (Table 1).

Table 1

Institutions of organic economy management that provide for integration of agricultural production and nature-resource sphere

\begin{tabular}{|l|l|}
\hline Institutions & \multicolumn{1}{|c|}{ Institutions of organic economy management } \\
\hline \multirow{5}{*}{ Formal } & Organic standardization and certification \\
\cline { 2 - 3 } & Licensing \\
\cline { 2 - 3 } & Ecological audit and monitoring \\
\cline { 2 - 3 } & Subsidization and penal sanctions \\
\cline { 2 - 3 } & Crediting and taxation \\
\cline { 2 - 3 } & Insurance and compensations \\
\hline & Legal responsibility and power \\
\hline \multirow{5}{*}{ Informal } & Public control \\
\cline { 2 - 2 } & Education and upbringing \\
\cline { 2 - 2 } & Ecological self-awareness \\
\cline { 2 - 2 } & Professional self-awareness \\
\cline { 2 - 2 } & Ethics and morals \\
\cline { 2 - 2 } & Cultural values \\
\hline
\end{tabular}

Formal institutions contour directions of organic farming and specificities of organic production, as well as form conditions for the creation of its market. Informal institutions, though represented as being an important component of the institutional environment, are poorly assessable with respect to their real influence on the development of organic production. It is in the first place connected with the fact that the period of the rise of organic farming essentially affected the agrarians and rural people's psychology, made them change their way of thinking and mode of life, and recollect traditions of husbandry management.

Active representatives of rural community and entrepreneurs have become initiators of ideological and cultural changes in the process of transition to the organic type of agricultural management, and of the denial of present-day sometimes excessively intense methods of agricultural production. The consumers' stereotypes were also broken, as well as their behaviour changed due to newly opened opportunities of leading a healthy life and eating safe food. 
Institutional environment of organic production in Ukraine is represented by such of its components as institutions called to facilitate production development and adapt it to international standards. Among these, the most influential and organic-oriented institutions are as follows: "BioLan Ukraine", an international public association of bio-production participants, and "Naturprodukt", an association of organic agricultural production participants. Besides, the Federation of Organic Movements in Ukraine is an active participant for the improvement of the institutional environment. The latter was founded for activation of organic production in the context of consolidation of efforts by scientific and business structures interested in production and spreading of ecologically safe products cultivated and processed with a caring attitude towards the environment (Chudovska, 2012). In practice, the caring attitude is expressed through the performance as follows:

- preservation and reproduction of the environment due to the introduction of organic technologies;

- assistance in the development of systems of organic and bio-dynamic agriculture for agro-producers with the use of the best national and world scientific and practical experience, and propagation of respective programs;

- assistance in the development of reference documents in the sphere of organic education, writing and publication of scientific-methodical literature, manuals, guidebooks, periodical editions;

- assistance in the formation in all regions of Ukraine of the network of producers and processors of organic production who would not only develop its export but form the domestic organic market.

The shaping factor of organic production's institutional environment, taking into account its specificity, shall be represented by a system of guarantee with all totality of standards and institutions that specialize in inspection and certification of organic enterprises and their products. The Organic Standard is a leading institution of certification in Ukraine, a state body accredited by the International Federation of Organic Agriculture Movements (IFOAM). It performs inspection and certification of the processes of production, processing and marketing of organic agricultural commodities. This element of the institutional structure of organic movement development certifies organic enterprises and their production on the basis of major international standards.

It should be remembered that the product is recognized as organic only when certified according to established procedure, found to comply with established standards and correspondingly marked. The product's assessment takes place with the consideration of national and international standards that verify its conformity within all chains of the production from the point of view of its influence on the environment (Andreyeva, Kharichkov, 2010).
There are 19 organizations in Ukraine accredited to certify agricultural enterprises according to the EU legislation, and national organic producers can, therefore, export their certified commodities to the European Union with no additional import approvals. However, strange as it is, such enterprises cannot be officially recognized as organic producers in Ukraine since legal framework in this country is not yet modified to conform with European requirements, and no legal instruments are yet developed to establish the procedure of economic performance.

Institutional-legal problems encountered in the process of introduction of organic farming in Ukraine require their urgent solutions and represent as follows: 1) absence of a respective legal framework, in the first place, fundamentallaw that would meet the requirements of international legislation with respect to the regulation of organic production and its certification;

2) absence of an efficient national system of certification and control of organic economies and their products;

3) absence of respective domestic infrastructure (associations/unions/centres of organic commodity producers);

4) necessity of integration into world structures (EU, IFOAM) and getting access to world markets for organic production;

5) necessity in due informational support (popularization of organic farming technologies, ecological education of population and agricultural producers, producers' consultative support, special trainings for managers and employees).

Integration of Ukraine into world economics, namely, the country's intention to join the European Union, the EU-Ukraine Association Agreement, the WTO membership, the country's activity in other world organizations and associations in conditions of intense globalization leads to increased competition in domestic and world markets. This, in its turn, necessitates the production of highly qualitative and competitive agricultural commodities, which, in the first place, are represented by the organic (ecological) products.

\section{Features of placement and specialization of agrarian enterprises for the production of organic products}

The organic trend in Ukrainian agriculture is now gaining the ground and it is, therefore, essentially important that a legal framework was instilled with it. For example, the Organic Agricultural Commodity and Raw Material Production and Turnover Act that came into effect in 2014 is called to strengthen responsibility of all producers in the agrarian market since this instrument presupposes implementation of the system of control over all steps of organic commodity production (Law "Organic Agricultural Commodity and Raw Material Production and Turnover”, 2014). The Act 
also establishes procedures of production/processing inspection and certification on the level of operators.

The organic operator can be defined as a physical person or legal entity, irrespective of ownership, an organizational/legal form of activity who, keeping to provisions of Ukrainian law in effect, undertakes production, processing, storage, and realization of organic commodities.

We have carried out the institutional distribution of organic operators within national market according to such differential attributes as territorial belonging; organizational/legal forms of performance; field of activity; certification bodies functioning in the country; certification standards and certification status.

Information based on the data available from the Organic Market Development in Ukraine, a SwissUkrainian project. Thus, as of 31 December 2015, there were 208 organic operators in Ukraine, inclusive of 127 producers and 81 other operators. Operators perform in Ukrainian administrative region as presented in Table 2. It should be noted that some operators do not give their consent for publication of their data, thus complicating analysis efforts.

Table 2

Organic producers and operators in Ukraine

\begin{tabular}{|c|c|c|c|}
\hline No. & Regions & $\begin{array}{c}\text { Number of } \\
\text { producers }\end{array}$ & $\begin{array}{c}\text { Number of organic } \\
\text { operators in the region } \\
\text { (inclusive of producers) }\end{array}$ \\
\hline 1 & Vinnytsia & 7 & 11 \\
\hline 2 & Volyn & 2 & 6 \\
\hline 3 & Dnipropetrovsk & 3 & 6 \\
\hline 4 & Donetsk & 2 & 3 \\
\hline 5 & Zhytomyr & 8 & 9 \\
\hline 6 & Zakarpattia & 8 & 12 \\
\hline 7 & Zaporizhzhia & 3 & 8 \\
\hline 8 & Ivano-Frankivsk & 0 & 1 \\
\hline 9 & Kyiv & 16 & 35 \\
\hline 10 & Kirovohrad & 4 & 4 \\
\hline 11 & Luhansk & 0 & 0 \\
\hline 12 & Lviv & 6 & 11 \\
\hline 13 & Mykolaiv & 4 & 4 \\
\hline 14 & Odesa & 4 & 13 \\
\hline 15 & Poltava & 4 & 5 \\
\hline 16 & Rivne & 2 & 6 \\
\hline 17 & Sumy & 0 & 1 \\
\hline 18 & Ternopil & 3 & 3 \\
\hline 19 & Kharkiv & 9 & 10 \\
\hline 20 & Kherson & 19 & 25 \\
\hline 21 & Khmelnytskyi & 2 & 2 \\
\hline 22 & Cherkasy & 1 & 3 \\
\hline 23 & Chernihiv & 7 & 8 \\
\hline 24 & Chernivtsi & 1 & 2 \\
\hline \multirow[t]{2}{*}{25} & \begin{tabular}{|l|} 
Autonomous \\
Republic of Crimea
\end{tabular} & 12 & 20 \\
\hline & Total: & 127 & 208 \\
\hline
\end{tabular}

Source: (Ukrainian Organic Production Business Reference Book, 2014)
As appears from Table 2, organic operators are predominantly concentrated in the Kyiv region (35, or $16.82 \%$ out of their total number in Ukraine). Among other regions-leaders in availability of organic operators we can mention Kherson region with 25 operators (12.01\%), Odesa-13 (6.25\%), Zakarpattia-12(5.8\%), Lviv - 11 (5.29\%), Vinnytsia regions - 11 (5.29\%), and the Republic of Crimea - 20 operators (9.62\%). It is almost in the half of Ukrainian regions, namely, Ivano-Frankivsk, Chernivtsi, Ternopil, Khmelnytskyi, Sumy, Poltava, Cherkasy, Kirovohrad, Donetsk, and Mykolaiv regions, the number of organic operators is insignificant and varies from 1 to 5 . It is only the Luhansk region that features none organic operators, though the region is characteristic for great natural perspectives for the successful development of organic production due to the huge agricultural background. Among organic operators, the biggest share belongs to producers of organic production whose territorial distribution is close to the same of organic operators on the whole. Thus, the biggest number of organic producers is concentrated in the Kherson (19, or $14.96 \%$ out of their totality) and Kyiv regions (16, or $12.6 \%$ ). If the organizational/legal form of economic activity is considered (Fig. 1), organic operators predominantly perform as business partnerships (57.10\%), and private enterprises $(23.60 \%)$ where the farming economies take over the half (56.76\%).

Operators of organic production work in different agricultural branches. Some subjects of economic management are issued certificates where only one type of activity is indicated, some other were permitted to perform in two or more types of certified activity. The latter prevail since one and the same operator is capable of growing organic production, processing it, and sale in the national market or conducting export/import operations, etc. Major types of certified activity are as follows: crop farming (inclusive of wild crop farming), cattle-breeding (inclusive of bee farming), processing, trade, export and import, etc. Table 3 represents the territorial distribution of organic commodity producers by major branches of agricultural production.

Regarding the structure of the market in the aspect of the production of different organic commodities, it should be noted that organic cereals, beans, and sunflower are the most developed markets that represent major export commodity groups predominantly realized in the European market. Asian countries are insufficiently represented in the export structure, though Egypt and Turkey, besides the $\mathrm{EU}$, are the biggest importers of organic soy.

World demand for the most popular groups of products predefines the formation of Ukrainian organic operators' assortment policy since up to $70 \%$ of produced organic commodities are exported (Sava, Sydoruk, Oliynyk, Dovgan, 2014), and only 30\% are consumed by the domestic market. The subjects of economic management should have focused on 
Vol. 4, No. 4, 2018
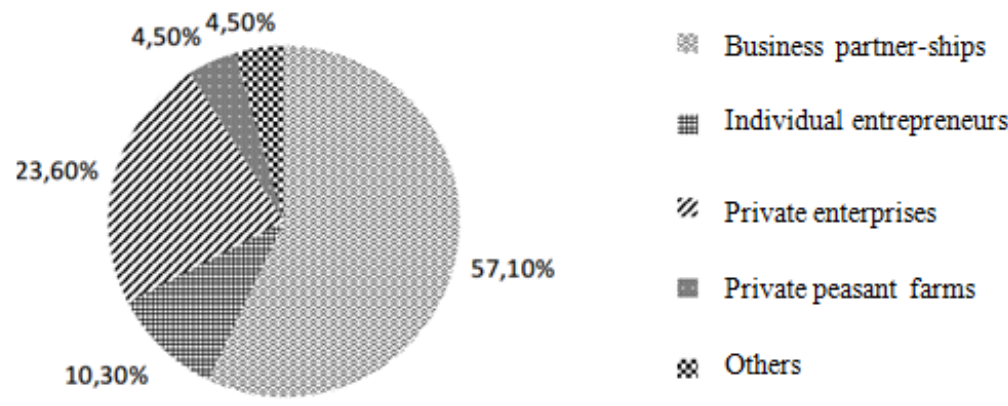

Figure 1. Organizational-legal structure of organic operators

Source: Ukrainian Organic Production Business Reference Book, 2014

national consumers since the national demand for organic production also increases. However, spreading of organic production in Ukraine still encounters serious obstacles, which are poor assortment of presented production, insufficiently branched sales channels, the population's low awareness, etc. Thus, it is a crop farming primary production that prevails in the structure of export. Further perspectives on national crop farming producers are focused on organic fruits and vegetables, these markets actively expand. On the contrary, the share of organic cattle-breeding products is rather insignificant due to inharmonious technical

Table 3

Territorial distribution of organic producers by major branches of agricultural production

\begin{tabular}{|c|c|c|c|c|c|c|c|c|c|c|c|c|c|c|c|}
\hline \multirow[b]{3}{*}{ No } & \multirow[b]{3}{*}{ Regions } & \multirow{3}{*}{ 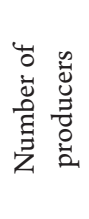 } & \multicolumn{8}{|c|}{ Crop farming } & \multicolumn{5}{|c|}{ Cattle breeding } \\
\hline & & & \multirow{2}{*}{ 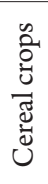 } & \multirow{2}{*}{ 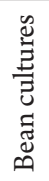 } & \multirow[b]{2}{*}{ 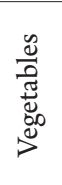 } & \multirow[b]{2}{*}{ 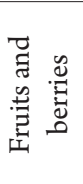 } & \multicolumn{3}{|c|}{ Technical cultures } & \multirow[b]{2}{*}{ 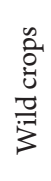 } & \multirow[b]{2}{*}{ 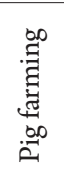 } & \multirow[b]{2}{*}{ 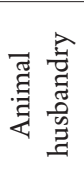 } & \multirow[b]{2}{*}{ 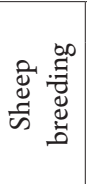 } & \multirow[b]{2}{*}{ 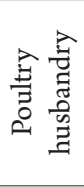 } & \multirow{2}{*}{ 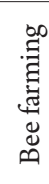 } \\
\hline & & & & & & & 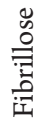 & 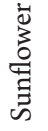 & $\begin{array}{l}\hat{\vec{n}} \\
\stackrel{0}{0} \\
\mathscr{\omega}\end{array}$ & & & & & & \\
\hline 1 & Vinnytsia & 7 & + & + & + & + & + & & & + & & + & & + & \\
\hline 2 & Volyn & 2 & + & & & & & & & + & & & & & \\
\hline 3 & Dnipropetrovsk & 3 & + & & & & & & & & & & & & \\
\hline 4 & Donetsk & 2 & & & + & + & & + & & & & & & & \\
\hline 5 & Zhytomyr & 8 & + & + & + & & & & & & & + & + & + & + \\
\hline 6 & Zakarpattia & 8 & & & + & + & & & & + & & & & & + \\
\hline 7 & Zaporizhzhia & 3 & & & & & & & & + & & & & & \\
\hline 8 & Ivano-Frankivsk & 0 & & & & & & & & & & & & & \\
\hline 9 & Kyiv & 16 & & + & + & + & & + & + & + & + & + & & + & \\
\hline 10 & Kirovohrad & 4 & & + & & & & & & & & + & & & \\
\hline 11 & Luhansk & 0 & & & & & & & & & & & & & \\
\hline 12 & Lviv & 6 & + & + & + & & & + & & + & & & & & \\
\hline 13 & Mykolaiv & 4 & & + & & + & & & & & & & & & \\
\hline 14 & Odesa & 4 & & & + & + & & + & & & & & & & + \\
\hline 15 & Poltava & 4 & + & & & & & & & & & & & & \\
\hline 16 & Rivne & 2 & + & + & + & & & + & & + & & & & & \\
\hline 17 & Sumy & 0 & & & & & & & & & & & & & \\
\hline 18 & Ternopil & 3 & + & & + & & & & & & & + & & & \\
\hline 19 & Kharkiv & 9 & + & + & + & & & & & & & & & + & \\
\hline 20 & Kherson & 19 & + & + & & & & + & & & & & & & \\
\hline 21 & Khmelnytskyi & 2 & & & & & & & & + & & & & & \\
\hline 22 & Cherkasy & 1 & + & & & & & & & & & & & & \\
\hline 23 & Chernihiv & 7 & + & + & + & & & & & & & + & & & + \\
\hline 24 & Chernivtsi & 1 & & & & & & & & + & & & & & \\
\hline \multirow[t]{2}{*}{25} & $\begin{array}{l}\text { Autonomous } \\
\text { Republic of Crimea }\end{array}$ & 12 & + & & & + & & & & + & & & & & + \\
\hline & Total: & 127 & & & & & & & & & & & & & \\
\hline
\end{tabular}

Source: Ukrainian Organic Production Business Reference Book, 2014 
regulations and standards, which prevent national agricultural production from being competitive in the European market at the expense of its quality. The Ministry of Agrarian Policy and Food, Ukraine, seeks for harmonization of all legal and normative parameters with respect to perspectives of organic livestock.

That would allow for the export of processed products and live weight with corresponding quality confirmation. Organic cattle-breeding in Ukraine is represented by horned cattle, pigs, sheep, goats, and poultry. The most dynamic figures of development are featured with organic milk from horned cattle where the raw material is processed for the subsequent production of milk products. Organic poultry rising is also regarded to have good perspectives in Ukraine (hen, duck, goose) (Klitna, Bryzhan, 2013). It is also interesting to trace the institutional distribution of organic operators by certifying bodies accredited to perform in Ukraine. Loosely, they can be divided into two groups: those included in the official List approved by the Commission of the European Union (Resolution (EC) No. 1235/2008 as of 08 December 2008, as revisited on 01 July 2013), and those that were not (Table 4).

Thus, the first group performing in the national organic market includes 14 foreign certifying bodies from such countries as Austria, Italy, the Netherlands, Germany, Turkey, France, and Switzerland, and the only one certifying body from Ukraine - the Organic Standard, recognized in the European Union and Switzerland. The second group is made up of one certifying body which is the Biokontroll Hungária Inspection and Certification Nonprofit Ltd. (Hungary). Table 4 represents how organic operators are distributed between certifying bodies. Distribution refers to only 170 national operators since there is no respective official statistics with regard to Ukraine. The data were taken from the open lists of organic operators available on sites of certifying bodies, and from the Ukrainian Organic Production Business Reference Book. It is the available information on the activity of 170 organic operators that was taken as a basis for the present study.

As appears from Table 4, Ukrainian organic operators are predominantly certified by the Organic Standard Ltd, a national certifying body, while the Ekolojik Tarim Kontrol Organizasyonu (ETKO) from Turkey takes the second place. The leadership of the aforesaid certifying bodies in Ukrainian organic market is explained by the fact that, according to Appendix IV of Resolution No. $1627 / 2011$ as of 6 December 2011, these two companies were officially recognized by the European Union and included into a list of controlling bodies that perform outside the EU borders.

The situation actually allowed the Organic Standard Ltd and Ekolojik Tarim Kontrol Organizasyonu (ETKO) to monopolize the market for certification of organic commodities made by producers who undertake their export to Europe. The matter is that, according to new provisions of the Resolution No. $1627 / 2011$ as of 6 December 2011, the commodities that have been certified by the controlling body listed hereinabove are allowed for the export in European countries with no additional import approvals. Such a procedure, in the first turn, essentially stimulates organic producers' export activity. Secondly, it aims at the enhancement of consumer's trust in the quality of products certified by the aforesaid controlling bodies.

The clients of other certifying companies active in Ukraine within the studied period underwent the legislatively different procedure of export of organic production to the EU countries from third countries (Novak, 2016). For example, the enterprise had to be certified by a controlling body internationally accredited according to a standard of organic production recognized by the European Commission as equal to the EU standard. After the contract is signed, the importer should receive the import approval from the state competent body of his native country. According to the procedure, it should take up to 4 weeks, though, practically, it may last for 2 months. Each batch of organic produce to be shipped is accompanied with the export certificate issued by exporter's controlling body thus allowing for goods' customs clearance as organic production.

\section{Further perspectives of development of agrarian enterprises with organic production on the basis of improvement of institutional regulation and certification}

Hence, little wonder that national organic operators' decision to cooperate with the above-stated certifying companies came from the opportunity of making use of a simplified export regime to the countries of the European Union. Beside operators' differentiation by the organic product's certifying bodies, there is no less important differentiation by the standards according to which operator's activity itself is certified. The basic regulatory standards and rules are as follows: the EU standards - Council Regulation (EC) 834/2007, Commission Regulation (EC) 889/2008, Commission Regulation (EC) 1235/2008; US Department of Agriculture (USDA), National Organic Program (NOP); Japanese Agricultural Standard (JAS), a Japanese law concerning standardization and correct marking of agricultural and forestry products with respective provisions for organic production; and the Swiss Organic Regulation.

Certification under the standard that is equivalent to the Council Regulation (EC) 834/2007 and the Commission Regulation (EC) $889 / 2008$ is widely popular with Ukrainian organic operators (over 90\%). Certified according to European standards, a significant number of the economic entities in the market for organic agricultural production (30\%) have made additional use of the American USDA National 
Vol. 4, No. 4, 2018

Table 4

Structural distribution of organic operators by certifying bodies performing in Ukraine

\begin{tabular}{|c|c|c|c|c|c|c|c|c|c|c|}
\hline \multirow{2}{*}{ No } & \multirow{2}{*}{ Certifying body } & \multirow{2}{*}{$\begin{array}{l}\text { Body's country } \\
\text { of registration }\end{array}$} & \multirow{2}{*}{$\begin{array}{c}\text { Certifying } \\
\text { body's code }\end{array}$} & \multicolumn{6}{|c|}{ Certification directions } & \multirow{2}{*}{$\begin{array}{l}\text { Number } \\
\text { of organic } \\
\text { operators }\end{array}$} \\
\hline & & & & A & B & $\mathrm{C}$ & $\mathrm{D}$ & $\mathrm{E}$ & $\mathrm{F}$ & \\
\hline \multicolumn{11}{|c|}{$\begin{array}{l}\text { According to official List approved by the Commission of the European Union } \\
\text { (Resolution (EC) No. 1235/2008 as of 08 December 2008, as revisited on 01 July 2013) }\end{array}$} \\
\hline 1 & Organic Standard & Ukraine & UA-BIO-108 & + & + & - & + & - & - & 95 \\
\hline 2 & Institute for Marketecology (IMO) & Switzerland & UA-BIO-143 & + & + & - & + & - & + & 15 \\
\hline 3 & Ecocert SA & France & UA-BIO-154 & + & - & - & - & - & - & 0 \\
\hline 4 & Austria Bio Garantie GmbH & Austria & UA-BIO-131 & + & + & - & - & + & + & 3 \\
\hline 5 & SGS Austria Controll-Co.GmbH & Austria & UA-BIO-159 & + & - & - & + & - & - & 1 \\
\hline 6 & Control Union Certifications & Netherlands & UA-BIO-149 & + & - & - & + & - & - & 2 \\
\hline 7 & $\begin{array}{l}\text { Ekolojik Tarim Kontrol } \\
\text { Organizasyonu }\end{array}$ & Turkey & UA-BIO-109 & + & - & - & + & - & - & 34 \\
\hline 8 & $\begin{array}{l}\text { CERES Certification of } \\
\text { Environmental Standards GmbH }\end{array}$ & Germany & UA-BIO-140 & + & + & - & + & - & - & 2 \\
\hline 9 & Abcert AG & Germany & UA-BIO-137 & + & - & - & + & - & - & 8 \\
\hline 10 & Lacon $\mathrm{GmbH}$ & Germany & UA-BIO-134 & + & - & - & - & - & - & 0 \\
\hline 11 & QC\&I GmbH & Germany & UA-BIO-153 & + & - & - & + & - & - & 0 \\
\hline 12 & BCS Oko-Garantie GmbH & Germany & UA-BIO-141 & + & - & - & + & + & - & 0 \\
\hline 13 & Bioagricert S.r.l. & Italy & UA-BIO-132 & + & - & - & + & - & - & 0 \\
\hline 14 & ICEA & Italy & UA-BIO-115 & + & - & - & + & - & - & 1 \\
\hline 15 & Suolo e Salute srl & Italy & UA-BIO-150 & + & - & - & - & - & - & 2 \\
\hline \multicolumn{11}{|c|}{$\begin{array}{l}\text { Not included to official List approved by the Commission of the European Union } \\
\text { (Resolution (EC) No. 1235/2008 as of 08 December 2008, as revisited on 01 July 2013) }\end{array}$} \\
\hline 16 & $\begin{array}{l}\text { Biokontroll Hungaria Inspection and } \\
\text { Certification Non-Profit LTD }\end{array}$ & Hungary & HU-ÖKO-01 & + & - & - & - & - & - & 7 \\
\hline & $\begin{array}{l}\text { Total: } \\
\end{array}$ & & & & & & & & & 170 \\
\hline
\end{tabular}

Notes: Directions of certification: A - non-processed plant products. B - living animals or non-processed animal products. C - Products of aquaculture and weed. D - Derived products of agricultural origin to be consumed as food. E - Derived products of agricultural origin to be consumed as forage. F - Planting stock and seeds.

Organic Program (NOP) and Swiss Organic Regulation (nearly 4\%) (Nykytiuk, 2009).

It should be noted that, according to Organic Agricultural Commodity and Raw Material Production and Turnover Act, Ukraine, adopted on 3 September 2013, No. 425-VII, not all active operators of organic market have the right to mark their products with the standard-form state logo composed of the inscription "Organic product" and respective graphical image. Art. 29 of the said law (General Requirements to Marking of Organic Production (Raw Materials)) provides that the use of the standard-form state logo and marking of organic production (raw materials) is only allowed if product's respective certificate is available. Marking of products at the stage of transition to organic production is done with the use of state logo where the same words, "Product at the stage of transition to organic production," are inscribed.

Thus, according to certification status, 140 Ukrainian organic operators ( $82.35 \%$ of the excerption) mark their commodities as "Organic product", 11 operators $(6.47 \%)$ - as "Product at the stage of transition to organic production". And, finally, 19 operators of organic market $(11.18 \%)$ feature products with no conformity to marking requirements suggested in the
Organic Agricultural Commodity and Raw Material Production and Turnover Act, Ukraine, and therefore, have no appropriate status. As provided by Ukrainian effective laws, such commodities should be marked as common traditional products since their operators live their first year of certification.

\section{Conclusions}

The components of the institutional environment of organic production in Ukraine exert somewhat multivector but predominantly restraining effect on the development of its market. Among negative effects, we should mention immaturity of legal framework, in particular, that of the state system of certification, stimulation and regulation of performance of organic enterprises; poor infrastructural provision for the inspection and certification of organic production, in particular, that of scientific-research establishments that could confirm organic products' quality and conformity to standards; poor infrastructure of organic market, in particular, with respect to its informational and marketing components.

Development of organic production presents itself as a counterbalance to processes of agricultural 
intensification; usefulness and safety of organic food is a precondition for the increase of the consumer demand, and its production is expected to become an impulse towards eco-saving attitude to the environment. Ukraine has chosen the way of sustainable development where organic production serves as some alternative to traditional agriculture. To understand the specificities of the formation of a national organic production market, one should consider the question of institutional distribution of organic operators.
The structure of the market for organic production to a great extent depends on the world's organic development trends, whereas domestic operators in the market are motivated by the chance to develop its new segments, the advantages of orientation towards European standards, and the world consumer demands. Besides, the popularization of organic agricultural food products within the domestic market gradually forms balanced demand and offer to be observed within the nearest future.

\section{References:}

Marmul, L. O., Novak, N. P. (2016). Rozvytok orhanichnoho vyrobnytstva v Ukrayini [Development of organic production in Ukraine]. Economics of Agro-Production Complex, vol. 9, pp. 26-32.

Ignatenko, M. M. (2015). Stratehiyi ta mekhanizmy upravlinnya rozvytkom sotsialnoyi vidpovidalnosti subyektiv hospodaryuvannya ahrarnoyi sfery ekonomiky [Strategies and mechanisms to manage development of social responsibility in subjects of economy of the agrarian sector of economics]. Kherson: Ailant (in Ukrainian).

Chudovska, V. A. (2012). Harmonizatsiya formalnykh ta neformalnykh instytutiv orhanichnoho vyrobnytstva [Harmonization of formal and informal institutions of organic production]. Balanced Nature Use, vol. 2, pp. 93-98.

Andreyeva, N. M., Kharichkov, S. K. (2010). Ekolohichno chyste vyrobnytstvo: instytutsiyni peredumovy, shlyakhy ta mekhanizmy yikh aktyvizatsiyi na Ukrayini [Ecologically clear production: institutional preconditions, ways and mechanisms of activation in Ukraine]. Economist, vol. 10, pp. 25-29.

Pro vyrobnytstvo ta obih orhanichnoyi silskohospodarskoyi produktsiyi ta syrovyny: Zakon Ukrayiny [Organic agricultural commodity and raw material production and turnover: Act Ukraine]. Retrieved from: http://zakon4.rada.gov.ua/laws/show/425-18 (accessed 24 June 2018)

Prokopchuk, N., Zigg, T., Vlasiuk, Yu. (ed.) (2014). Orhanik biznes-dovidnyk Ukrayiny [Ukrainian organic production business reference]. Retrieved from: http://www.ukraine.fibl.org/index.php?id=ua-publications (accessed 24 June 2018)

Sava, A. P., Sydoruk, B. O., Oliynyk, O. R., Dovgan, S. V. (2014). Orhanizatsiyno-ekonomichnyy mekhanizm zabezpechennya vyrobnytstva ekobezpechnoyi silskohospodarskoyi produktsiyi [Organizational economic mechanism to provide for production of eco-safe agricultural production]. Ternopil: Krok. (in Ukrainian)

Klitna, M. R., Bryzhan, I. A. (2013). Stan i rozvytok orhanichnoho vyrobnytstva ta rynku orhanichnoyi produktsiyi $\mathrm{v}$ Ukrayini [Situation with and development of organic production and organic market in Ukraine]. Effective Economics, vol. 10. Retrieved from: http://www.m.nayka.com.ua/?op=1\&j=efektyvnaekonomika\&s=ua\&z=2525 (accessed 24 June 2018)

Novak, N. P. (2016). Orhanizatsiyno-ekonomichni zasady rozvytku vyrobnytstva orhanichnoyi produktsiyi vahrarnykh pidpryyemstvakh [Organizational economic bases for development of organic production in agrarian enterprises]. Kherson: Aylant. (in Ukrainian)

Nykytiuk, O. A. (2009). Sertyfikatsiya i standartyzatsiya produktsiyi orhanichnoho zemlerobstva [Certification and standardization of organic farming production]. Agroecological journal, vol. 2, pp. 26-27. 